\title{
A research proposal for a new commentary
}

\section{on John}

\author{
Charles Landon \\ Hanau, Germany
}

\begin{abstract}
The author offers a research proposal for a new commentary on the Gospel of John, provisionally entitled An Internal Textual Commentary on John, Part I: A Commentary on the Apparatus to NA27; Part II: A Selective Commentary on the Apparatus to Tischendorf and Elliott \& Parker. In the proposal, he responds to criticism of his previous work on Jude offered by Peter Head in Novum Testamentum 61(2) 181-185. The proposed work on John will not exemplify thoroughgoing eclecticism in practice, but will instead measure (1) the internal strength of three major text-types, and (2) the internal strength of two editions of the Greek New Testament, NA27 and Westcott \& Hort (1881).
\end{abstract}

\section{PROPOSED TITLE OF THE COMMENTARY}

An Internal Textual Commentary on John, Part I: A Commentary on the Apparatus to NA27;

Part II: A Selective Commentary on the Apparatus to Tischendorf and Elliott \& Parker.

According to B M Metzger (1968:216) "most scholars ... are still inclined to regard the Alexandrian text as on the whole the best ancient recension and the one most nearly approximating the original." C-B Amphoux (1986:141), on the other hand, has written that "L'hypothèse de la priorité du texte 'occidental' revient à l'assimiler, dans ses variantes les plus considérables, au texte courant primitif." A third position has been adopted by J K Elliott (1992:27), that "no one family of manuscripts has the monopoly of truth", as a result of which MSS should be deemed equal in external value. The main aim of this proposed work will be to evaluate the comparative internal strengths of the 
Alexandrian, Western and Byzantine text-types This will be realized by examining a large number of variants in John. A secondary aim will be to evaluate the internal quality of two published editions of the NT, NA27 (Aland et al 1993) and Westcott \& Hort (1881). In the case of NA27, attention will be given to Amphoux's (1986:248) claim that the NA27 editors have often relegated the most primitive readings to the apparatus.

As the proposed title suggests, the analysis will be confined to internal evidence, and with the exception of external transcriptional argumentation, extermal discussions will not be included. As G D Kilpatrick (1967:158) has put it, "It is better not to begin writing about better attestation until we have examined all the readings in the text of our author and have come to a decision about them." It is not planned to examine all of the readings in John, but at some stage one has to adopt a position about attestation, and the results of this study may clarify to the satisfaction of the present writer, whether or not it is reasonable to regard any given text-type as superior.

The commentary itself will examine 2000 variation units in John, selected from the apparatus to NA27, Tischendorf, the Majority text, Elliott \& Parker (1995), facsimile editions, and collations carried out by the present writer. Part I will concentrate on the NA27 apparatus. Part II will contain extra units selected from Tischendorf and Elliott \& Parker (1995), supplemented by data from collations. Units will be selected always with the main aim in consideration: that of evaluating the comparative internal strengths of the three text-types mentioned above. Editorial preferences in Hort and NA27 will also be cited, with the secondary aim of editorial evaluation in mind. Of the 2000 variation units displayed, approximately 1700 will generate discussions: this is because once a textual problem has been analysed, there is no point in repeating the same reasoning when the same problem reappears at a different unit. Around 300 units will therefore merely be listed in an appendix. Assuming 1700 units are discussed, at an average of four per page, the resultant commentary will occupy about 425 pages. To these will be added an introduction, seven appendixes, a conclusion and a bibliography.

Appendix A will help the reader to look up any variation unit where a given aspect of language, style or vocabulary is discussed, and will list a comprehensive range of stylistic sub-headings together with the variation unit references and readings particular to each. These data will be used to determine the extent to which any given text-type 
preserves (or tampers with) any stylistic feature special to John. Appendix A is therefore linked to the main aim of the research as stated above; likewise appendixes B and $C$. Appendix B will display all of the internally superior readings belonging to each text-type together with manuscript support, following the example of Zuntz (1953). Appendix C will display an internal assessment of all consistently cited witnesses excluding fragments. This assessment will make allowance for the presence of block mixture in Sinaiticus, and for the Western strain in P66 for example in chapters 6 and 7, as indicated by Fee (1993:221-243). Appendix C will thus follow the example of Elliott (1968).

Appendix D will record a list of questionable decisions in NA27, citing briefly the manuscript evidence from units where variants opposing NA27 are deemed superior on

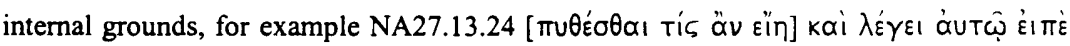
Tí ĖTIV BCL 06833892 pc (lat), with the NA27 reading printed before the bracket, and the rival demed internally superior after it. Along with appendixes $E$ and $F, D$ will be compiled with the secondary aim of editorial evaluation in mind. Appendix E will list some questionable decisions in Hort, and will be arranged like appendix D. Appendix F will list some questionable decisions common to NA27 and Hort, and will be arranged like appendixes D and E. Appendix G, meanwhile, will feature a list of "Readings Deemed Superior on Grounds of Previous Discussions" and will probably contain around

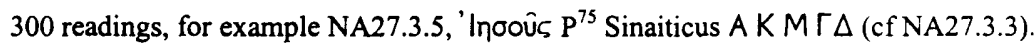

The present writer's short work on Jude (1996) prompted six reviews, the most detailed of which was that of P Head (1999:181-85). In order to justify the approach which will be adopted for John, I should like to respond to Head's critique, for the most part not to reject his criticism, but to show that it will be taken into account in the conception and execution of this new work. He has made five major points, each of which receives comment below.

- “... in practice Landon does not investigate ... external evidence and does not demonstrate as clearly as he might have done, the differences between a radical and a reasoned eclecticism" (Head 1999:181). This is a valid criticism of the work on Jude, but it is not applicable to this proposed work. With John, I propose to use internal evidence not to reconstruct an alternative Greek text of John or to 
illustrate thoroughgoing eclecticism in practice, but to test one pillar of Hort's text-historical theory, namely the alleged internal superiority of the Alexandrian text-type, and the alleged internal inferiority of the Western and Byzantine texttypes. If at the end of the analysis I am satisfied that there is strong evidence in favour of one particular text-type and against the others, then $I$ will be in a position to concede that external evidence should feature in text-critical decisions, and to abandon my previously stated preference for thoroughgoing eclecticism.

"The bulk of this work consists of a brief apparatus and discussion of 95 variation units in Jude. The variants and material for the apparatus were culled from various published editions, although Landon never makes clear how or why these 95 were chosen. NA27 offers 81 different units, six of which are not discussed by Landon" (Head 1999:182). Again, this is a justifiable criticism of the work on Jude. The apparatus for John will be compiled with the main aim of the work in mind: the MSS will in most cases be leading representatives of the three major textual groupings indicated for example in Metzger (1994:6-16). Citations from the fathers, and versional evidence, will also be presented with textual consanguinity in mind. A few units from NA27 will be deliberately omitted: (1) those with singular readings as the sole variants, and (2) those involving the commonest conjunctions.

- "First, it is important to note Landon's acknowledgement that the apparatus given for each variation unit is derived from secondary sources .... There is no indication that plates or individual manuscripts have been checked at any point. Thus an opportunity to check the accuracy of published editions was missed and unchecked errors may be [sic] perpetuated" (Head 1999:182). With John, the aim will not be to produce a definitive apparatus, although I am making collations, and I am consulting facsimile editions. It is not an aim of this work to check the accuracy of the published editions with a view to exposing inaccuracies in them, although checks are being made where necessary. 
- "Secondly, Landon took the decision to offer only a limited sample of manuscript evidence in support of each cited variant. This decision is justified on two grounds, neither of which really satisfied this reviewer. Landon firstly suggests that the information is available in C A Albin's commentary, Judasbrevet .... But I have not found this 35 year old Swedish commentary to be widely available. More significant is Landon's argument that a fuller listing of manuscript evidence is not relevant for arguments based on an eclectic method" (Head 1999:182). To the first point made here, one can only respond that Albin's commentary should be reprinted. The second criticism is entirely fair for Jude, but will not apply to the present work, since the latter will not be an eclectic study of John. I propose with John again to offer a limited sample of manuscript evidence, knowing full well that the IGNTP volumes are being produced for those who need a more complete conspectus of evidence, and that they will be made widely available.

"Of paramount importance for Landon is the criteria [sic] of the writer's style ... Here two general difficulties emerge which are not taken into account by Landon. First the stylistic features noted by Landon are quite dissimilar to the grammatical and lexicographical features characteristic of the work of Turner and Elliott, and may therefore provide a less firm foundation for predictions of "what the author is most likely to have written'" (Head 1999:184). The solitary example offered by Head to substantiate this claim (my admittedly flawed analysis of Jude unit 9.2) scarcely addresses the point he has made. I have indeed looked at stylistic features different to those explored by Turner and Elliott, but it is a nonsequitur to posit (without any proof) that my predictions about what an author is likely to have written are less valid than those of Turner and Elliott. The difference between my description of an author's style and what Turner has written on the subject is surely explicable by the fact that we were dealing with two different authors. So on this last point, Head's criticism is not accepted, although I should like to thank him for his extremely helpful critique of my work. 


\section{PREVIOUS WORK ON THE TEXT OF JOHN}

J Delobel (1977:317-323) has written a good overview of methodological literature on the Bodmer papyri of John, but (with the exception of Fee 1968) none of the works cited by him deals with internal evidence. Thus far, limited internal studies have been undertaken by Fee $(1968,1970)$ and Metzger (1994). The work by Fee (1968) concentrates mainly on scribal tendencies in $\mathrm{P}^{66}$ and on its textual character, although a few internal problems are examined, and he draws attention to the excellent grammar of Abbott (1906). Fee's article on personal names (1970) is extremely valuable, and covers great breadth in a short space. Metzger's Textual Commentary (1994) is limited to variants deemed of significance to exegetes, but is always worth consulting. In selecting manuscripts according to text-types, the contributions of Zimmermann (1958), Boismard (1957), K Aland (1957) and Fee (1993) have all been consulted, and a provisional list of witnesses to be cited appears directly below.

\section{A PROVISIONAL LIST OF WITNESSES FOR THE APPARA- TUS TO JOHN}

\subsection{Early Alexandrian Witnesses \\ $\mathrm{P}^{66}$ (except chapters 6 \& 7) $\mathrm{P}^{75}$ Sinaiticus (8.39-21.25) B Clement Origen}

\subsection{Late Alexandrian Witnesses}

C L T W 335798921241 bo Didymus

\subsection{Western Witnesses}

$\mathrm{P}^{66}$ (chapters 6 \& 7 only) Sinaiticus (1.1-8.38) D it sys syc_ Irenaeus Justin Jerome Tertullian Cyprian

\subsection{Byzantine Witnesses}

A K M P S V $\Pi \Omega \omega$ [the small omega designates the Majority text] 


\subsection{Other Witnesses of Value}

$\mathrm{P}^{5} \mathrm{P}^{22} \mathrm{P}^{28} \mathrm{P}^{39} \mathrm{P}^{44} \mathrm{P}^{45} \mathrm{P}^{52} \mathrm{P}^{55} \mathrm{P}^{59} \mathrm{P}^{63} \mathrm{P}^{76} \mathrm{P}^{80} \mathrm{P}^{84} \mathrm{P}^{95} \Theta \underline{\mathrm{f}} \underline{\mathrm{13}} 565700$

It may be found necessary to add two or three extra witnesses to the groups given above. There will be no need to collate the papyri, since we now have the accurate work of Elliott \& Parker (1995) to rely on. The witness of Sinaiticus A B C D will be checked in facsimile editions. Full collations are being made of L T W 335798921241 K M P S $\mathrm{V} \Pi \Omega$, using microfilm records. The result will be a compact apparatus, but one in which the leading witnesses in each textual stream will be fully represented. In view of the generally accepted realisation that the "Caesarean" text-type is in reality just a mixture of the Alexandrian and Western streams, mixed manuscripts such as $\Theta \mathrm{f} \underline{1} \mathbf{f} \underline{3}$ 565 and 700 will not be represented in appendix $\mathrm{C}$, although it should be noted that at a few individual units they are Westward-leaning.

\section{Works consulted}

Abbott, E A 1906. Johannine grammar. London: A \& C Black.

Aland, B et al 1993. Novum Testamentum Graece. Stuttgart: Deutsche Bibelgesellschaft. Aland, K 1957. Papyrus Bodmer II. Ein erster Bericht. TLZ 82, 161-84.

Amphoux, C-B \& Vaganay, L 1986. Initiation à la critique textuelle du Nouveau Testament. $2^{\mathrm{e}}$ édition, entièrement revue et actualisée par Christian-Bemard Amphoux. Paris: les Editions du Cerf.

Boismard, M-E 1957. Le papyrus Bodmer II (P66). RB 64, 363-89.

Delobel, J 1977. The Bodmer Papyri of John: A short survey of the methodological problems, in De Jonge, M (ed), L'Evangile de Jean: Sources, rédaction, théologie. Leuven: Leuven University Press.

Elliott, J K 1968. The Greek Text of the Epistles to Timothy and Titus. Salt Lake City: Utah University Press. (SD 36).

- 1992. Essays and studies in New Testament textual criticism. Cordoba: Ediciones el Almendro. 
Elliott J K (ed) 1993. The language and style of the Gospel of Mark: An edition of CH Turner's "Notes on Marcan Usage" together with other comparable studies. Leiden: Brill.

Elliott, W J and Parker, D C 1995. The New Testament in Greek IV: The Gospel According to St John, Vol I The Papyri. Leiden: Brill. (NTTS 20.)

Epp E J \& Fee, G D 1993. Studies in the theory and method of New Testament textual criticism. Grand Rapids: Eerdmans. (SD 45.)

Head, P M 1999. Review of Landon (1996). NovT 61(2), 181-85.

Kilpatrick, G D 1967. Style and text in the Greek New Testament, in Daniels \& Suggs (eds), Studies in the history and text of the New Testament in honour of Kenneth Willis Clark. Salt Lake City: Utah University Press..(SD 29.)

Landon, C 1996. A Text-Critical study of the Epistle of Jude. Sheffield: Sheffield Academic Press. (JSNTS 135.)

Metzger, B M 1968. The Text of the New Testament: Its transmission, corruption and restoration. Oxford: Clarendon Press.

- 1994. Textual commentary on the Greek New Testament. 2nd ed. Stuttgart: Deutsche Bibelgesellschaft.

Tischendorf, C 1869. Novum Testamentum Graece. 8th ed Vol I. Leipzig: Giesecke \& Devrient.

Westcott, B F \& Hort, F J A 1881. The New Testament in the original Greek: Introduction, Appendix. London: Macmillan.

Zimmermann, H 1958. Papyrus Bodmer II und seine Bedeutung für die Textgeschichte des Johannes-Evangeliums. $B Z(2), 214-243$.

Zuntz, G 1953. The text of the Epistles: A disquisition upon the Corpus Paulinum. London: Oxford University. 